Schutter, J. \& Wilson, P. W. (1955). J. gen. Microbiol. 12, 446-454

\title{
Patterns of Enzymic Adaptation in Species of the Genus Azotobacter
}

\author{
BY JANE SCHUTTER AND P. W. WILSON \\ Department of Bacteriology, University of Wisconsin, Madison, \\ Wisconsin, U.S.A.
}

SUMMARY: Fourteen strains of the Azotobacter agile-A. vinelandii group were classified into one or the other of the above species by morphological, cultural and growth characteristics. The groups were then surveyed by a study of oxidative reactions of whole cell suspensions on some intermediates of the tricarboxylic acid (TCA) cycle: acetate, malate, succinate, $\alpha$-ketoglutarate and citrate.

All strains grew readily in a nitrogen-free medium. Organisms that were morphologically large rods or ovoid cells produced a green water-soluble pigment in an irondeficient medium, and did not utilize mannitol or nitrate in the absence of another carbon or nitrogen source. Strains composed of smaller rods also produced the green pigment, and would utilize mannitol and nitrate. The first group was classified as Azotobacter agile, and the second as $A$. vinelandii.

$Q_{\mathrm{O}_{2}}(\mathrm{~N})$ values on the TCA substrates tested did not indicate group variation. However, 15-24 hr. cells of the Azotobacter agile group as a unit did oxidize succinate with a shorter lag period (not greater than $30 \mathrm{~min}$.) than strains of the $A$. vinelandii group (not less than 50 min.). A similar response to malate was noted, but in contrast most strains of $A$. vinelandii oxidized $\alpha$-ketoglutarate after a shorter lag than did strains of $A$. agile. Citrate oxidation was variable among strains; all organisms but $A$. vinelandii $\mathrm{O}$ were apparently inhibited by the chelation of magnesium (and possibly calcium) by citrate. The physiological and oxidative responses of freshly isolated strains did not differ markedly from those of laboratory cultures of the same species.

For many years now the role of physiological methods in establishing the taxonomic position of a bacterial strain has been recognized and accepted, but some investigators are often troubled by the exclusive use of what appears to them to be rather crude biochemical tests in determining an organism's 'physiology'. Undoubtedly at one time or another, most bacterial physiologists have wondered whether more modern techniques of enzyme specification could not be applied to taxonomic questions. The difficulties of doing so on the large scale demanded by the survey of hundreds of bacterial isolates are recognized to be formidable though certainly not insurmountable. For the time being, at least, the conventional methods represented by such a physiological description as 'acid and gas on lactose', for identification and classification, must remain the basic set for initial screening. But perhaps it is not too early to begin studies in which the more advanced quantitative methods are applied to special problems that have been defined through the conventional techniques.

As an example of such an approach we have recently examined some of the enzymic properties of representative strains of the Azotobacter agile-vinelandii group. ('Group' is used in this paper as a convenient term to include strains 
labelled either $A$. agile or $A$. vinelandii without any implication as to whether the group comprises one or more species; see Discussion.) For two reasons this group appears to offer a reasonably significant test case. First, the results of traditional methods have led to disagreement as to whether one or two species should be recognized; secondly, a considerable amount of information concerned with the enzymic properties of a few strains exists. Extension of such studies to other strains might help to decide whether the few gross morphological and physiological differences observed between members of the two groups can be correlated with more subtle differences in specific enzyme properties.

\section{METHODS}

Organisms used. Fourteen strains were used in this study, nine of which had been classified previously as Azotobacter agile or A. vinelandii. A tenth strain was received unclassified from Kansas State College and identified as $A$. vinelandii by morphology and by the following growth characteristics: ability to grow readily in a nitrogen-free liquid medium with the formation of a green water-soluble pigment when this medium is deficient in iron. The remaining four strains were fresh isolates of $A$. agile as determined by cell size and shape and by the foregoing growth properties. Source and classification of all strains are listed in Table 1.

The organisms were maintained on Burk's mineral salts medium with $2 \%$ (w/v) sucrose (Wilson \& Knight, 1952). A 2-3\% (v/v) inoculum was introduced into $100 \mathrm{ml}$. medium in a $500 \mathrm{ml}$. Erlenmeyer flask and shaken 350 r.p.m. at $30^{\circ}$ for $15-24 \mathrm{hr}$. Colonial characteristics were observed from growth on the same medium solidified with $1.5 \%$ agar.

Table 1. Source of strains of azotobacter

\begin{tabular}{|c|c|c|c|}
\hline \multicolumn{2}{|r|}{ Azotobacter agile } & \multicolumn{2}{|r|}{ Azotobacter vinelandii } \\
\hline Strain & Source & Strain & Source \\
\hline 9040 & $\begin{array}{l}\text { American Type Culture Col- } \\
\text { lection; R. L. Starkey, donor }\end{array}$ & 7492 & $\begin{array}{l}\text { American Type Culture Col- } \\
\text { lection; D. Burk, donor }\end{array}$ \\
\hline 7494 & ATCC; N. R. Smith, donor & 7496 & ATCC; N. R. Smith, donor \\
\hline $4 \cdot 4$ & $\begin{array}{l}\text { Stock culture of the University } \\
\text { of Wisconsin; originally from } \\
\text { Dr H. A. Barker, University of } \\
\text { California }\end{array}$ & 7484 & ATCC: N. R. Smith, donor \\
\hline S-1 & $\begin{array}{l}\text { Isolated from Lake Mendota, } \\
\text { Madison, Wisconsin by } \\
\text { J. Schutter }\end{array}$ & $\mathrm{O}$ & $\begin{array}{l}\text { Original strain from the } \\
\text { University of Wisconsin }\end{array}$ \\
\hline S-2 & $\begin{array}{l}\text { Lake Mendota, Madison, } \\
\text { Wisconsin }\end{array}$ & 3 & $\begin{array}{l}\text { Stock culture of the Uni- } \\
\text { versity of Wisconsin; } \\
\text { originally from R. L. } \\
\text { Starkey }\end{array}$ \\
\hline S-3 & $\begin{array}{l}\text { Lake Mendota, Madison, } \\
\text { Wisconsin }\end{array}$ & $\mathbf{K}$ & $\begin{array}{l}\text { From T. G. G. Wilson; } \\
\text { originally from Rothamsted } \\
\text { Experimental Station, } \\
\text { England }\end{array}$ \\
\hline S-4 & $\begin{array}{l}\text { Lake Mendota, Madison, } \\
\text { Wisconsin }\end{array}$ & K-S4 & $\begin{array}{l}\text { From J. O. Harris, Kansas } \\
\text { State College }\end{array}$ \\
\hline
\end{tabular}


Nitrate utilization. Because Green \& Wilson (1953) observed that Azotobacter vinelandii utilizes potassium nitrate in the absence of molecular nitrogen, while $A$. agile $4 \cdot 4$ does not, all strains were tested. A modification of the method of Horner \& Allison (1943) was used; $125 \mathrm{ml}$. flasks each containing $15 \mathrm{ml}$. Burk's media with $2 \%(\mathrm{w} / \mathrm{v})$ sucrose and $300 \mu \mathrm{g} . / \mathrm{ml}$. nitrate as $\mathbf{K N O}_{3}$ were inoculated with $0 \cdot 1 \mathrm{ml}$. active culture from a nitrogen-free medium. The flasks in $200 \mathrm{~cm}$. vacuum desiccators were maintained under $0.2 \mathrm{~atm}$. of oxygen and $\mathbf{0 . 8} \mathrm{atm}$. of hydrogen, the latter to prevent any fixation of atmospheric nitrogen. The desiccators were shaken 100 strokes/min. on a reciprocal shaker at $30^{\circ}$. After 4 days the $\mathrm{pH}$ value was determined. Evidence of visible growth was accompanied by rise in $\mathrm{pH}$ value owing to disappearance of nitrate ion. This simple test was occasionally checked by actual measurement of the amount of nitrate that disappeared by the method of Nelson, Kurtz \& Bray (1954).

Manometric experiments. Organisms to be tested for oxidative activity were removed at 15-24 $\mathrm{hr}$. from liquid cultures by centrifugation, washed once by suspending in 10 times the cell volume of cold $0 \cdot 2 \%(\mathrm{w} / \mathrm{v}) \mathrm{KCl}$ solution, recentrifuged and resuspended in a fresh portion of $\mathrm{KCl}$. Total nitrogen was determined by a semimicro-Kjeldahl method.

Standard manometric procedures were used to measure rate of oxygen uptake on sucrose and the tricarboxylic acid (TCA) intermediates: acetate, malate, succinate, $\alpha$-ketoglutarate, and citrate. $Q_{\mathrm{o}_{2}}(\mathrm{~N})$ values $\left(\mu 1 . \mathrm{O}_{2} / \mathrm{hr} . /\right.$ mg. $N$ ), corrected for the low endogenous respiration, were calculated after the end of the lag period from the rate of oxygen uptake on the linear part of the curve. Unless otherwise stated, the contents of Warburg vessels were: a volume of cell suspension containing $60-100 \mu \mathrm{g} . \mathrm{N} ; 80 \mu$ mole potassium phosphate buffer at $\mathrm{pH} 7 \cdot 0 ; 2 \mu$ mole $\mathrm{MgSO}_{4}$; water to make a total volume of $3.2 \mathrm{ml}$; $40 \mu$ mole substrate in the side arm; $0.1 \mathrm{ml} .20 \% \mathrm{KOH}$ in the centre well. The atmosphere was $50 \% \mathrm{O}_{2}$ plus $50 \% \mathrm{He}$, and the temperature was $\mathbf{3 6}^{\circ}$. For general characteristics of oxidations by the azotobacter under these conditions see Williams \& Wilson (1954).

\section{RESULTS}

\section{General morphological, cultural and physiological characteristics}

A primary separation of Azotobacter agile strains from those of $A$. vinelandii could be made on the basis of the morphology of young cells. The $A$. agile organisms were usually ovoid or spherical, measuring $2 \cdot 0 \times 2 \cdot 0-4.5 \mu$. The $A$. vinelandii organisms were smaller rods not exceeding $1.5 \mu$. in width and 3.0 $\mu$. in length (see Jensen, 1954). The colonies of the strains of $A$. vinelandii were gummy in contrast with the drier, smaller colonies of $A$. agile. After an incubation period of 1 week no strains of $A$. agile had grown visibly in liquid Burk's medium in which $2 \%$ mannitol had been substituted for sucrose; all the $A$. vinelandii strains grew within $24 \mathrm{hr}$. Likewise all strains of $A$. vinelandii, but none of $A$. agile, grew when $\mathrm{KNO}_{3}$ was the sole source of nitrogen.

Pigment formation varies according to the mineral content of the medium 
particularly that of iron and molybdenum (Wilson \& Knight, 1952). For test we have used Burk's medium without $\mathrm{Fe}+\mathrm{Mo}$ solution. Under these circumstances the Azotobacter vinelandii strains turned the medium a bright green, whereas the colour formed by $A$. agile was less intense. On ageing in the refrigerator the agar slopes of $A$. agile became reddish to purple, whereas those of $A$. vinelandii, which were originally greenish yellow, faded.

\section{Oxidative properties and enzymatic adaptation}

Table 2 summarizes the rates of respiration of the fourteen strains on typical TCA intermediates. Figs. 1 and 2 present the adaptative patterns for typical representatives of each type (similar figures for Azotobacter vinelandii $\mathbf{O}$ and for $A$. agile $4 \cdot 4$ are included in previous publications (e.g. Repaske \& Wilson, 1953; Williams \& Wilson, 1954). No consistent differences among the rates

Table 2. Rates of respiration by azotobacter strains with various substrates

\begin{tabular}{|c|c|c|c|c|c|c|}
\hline \multirow{3}{*}{. } & \multicolumn{6}{|c|}{ Substrate } \\
\hline & Sucrose & Acetate & Malate & Succinate & $\begin{array}{c}\alpha \text {-keto- } \\
\text { glutarate }\end{array}$ & Citrate* \\
\hline & \multicolumn{6}{|c|}{$Q_{\mathrm{O}_{2}}(\mathrm{~N}): \mu \mathrm{l} . \mathrm{O}_{2} / \mathrm{hr} \cdot / \mathrm{mg} \cdot \mathrm{N}$} \\
\hline Strain & \multicolumn{6}{|c|}{ Azotobacter vinelandii } \\
\hline $\mathrm{O}$ & 7,900 & 13,600 & 12,300 & 11,600 & 11,800 & 5,000 \\
\hline $\mathbf{K}$ & 8,300 & 16,800 & 16,200 & 20,200 & 14,900 & $\mathbf{3 , 3 0 0}$ \\
\hline 3 & 3,800 & 15,600 & 13,500 & 17,600 & 21,000 & 1,500 \\
\hline 7492 & 5,700 & 11,500 & 8,100 & 15,500 & 11,200 & $\mathbf{0}$ \\
\hline 7484 & 6,000 & 8,200 & 9,400 & 8,100 & 8,700 & Not tested \\
\hline 7496 & 8,700 & 10,700 & 14,600 & 14,300 & 11,200 & 0 \\
\hline \multirow[t]{2}{*}{ K-S 4} & 7,000 & 9,300 & 8,900 & 10,900 & 11,700 & $\mathbf{0}$ \\
\hline & \multicolumn{6}{|c|}{ Azotobacter agile } \\
\hline $4 \cdot 4$ & 10,700 & 13,500 & 16,500 & 17,600 & 12,600 & 3,600 \\
\hline 9040 & 13,100 & 22,200 & 17,500 & 18,400 & 11,300 & 1,900 \\
\hline 7494 & 12,300 & 13,900 & 13,900 & 13,200 & 10,400 & $\mathbf{2 , 8 0 0}$ \\
\hline S-1 & 7,800 & 12,400 & 9,600 & 13,600 & 9,500 & 2,200 \\
\hline S-2 & 13,400 & 14,500 & 20,700 & 17,900 & 6,600 & 1,100 \\
\hline S-3 & 13,200 & 16,800 & 15,300 & 13,600 & 4,300 & 2,600 \\
\hline S-4 & 14,800 & 16,500 & 17,100 & 16,700 & 3,500 & Not tested \\
\hline
\end{tabular}

of respiration could be correlated with the type of organism, but a study of results similar to those shown in Figs. 1 and 2 for the entire 14 strains suggested certain differences in the pattern of adaptation to a few of the substrates.

Over a period of 2 years experiments have been made to determine whether such patterns were consistent enough to allow any helpful differentiation between the two types. From the results we have concluded that the patterns of adaptation, at least with these 14 strains, are reasonably stable so that behaviour on succinate and to a lesser extent on $\alpha$-ketoglutarate and malate can differentiate between $A z o t o b a c t e r$ agile and $A$. vinelandii. Fig. 3 illustrates typical findings with 6 strains; the curves for the others showed similar clustering about the proper group of lines in this figure. Analogous though 


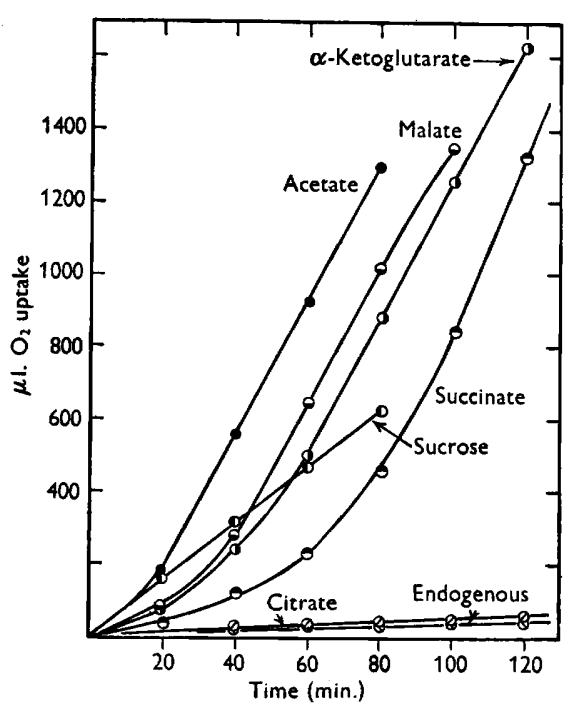

Fig. 1

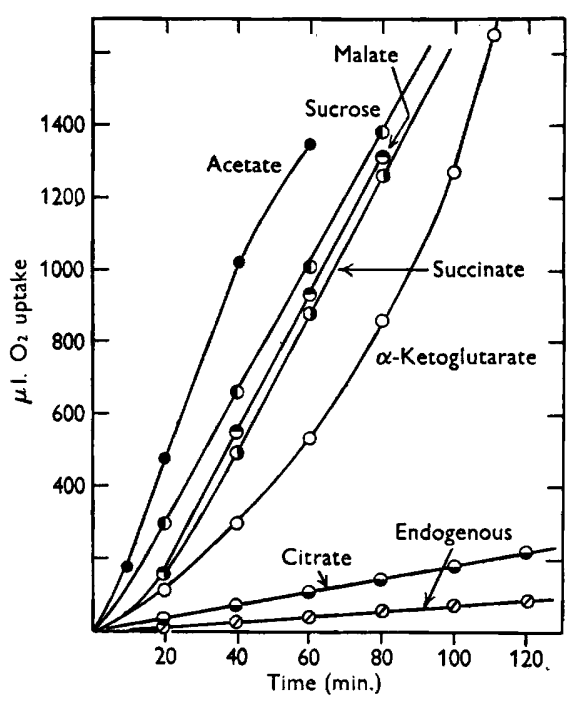

Fig. 2

Fig. 1. Respiratory activity of sucrose-grown Azotobacter vinelandii 7492 on sucrose and five substrates of the tricarboxylic acid cycle.

Fig. 2. Respiratory activity of sucrose-grown cells of Azotobacter agile S-1 on sucrose and five substrates of the tricarboxylic acid cycle.

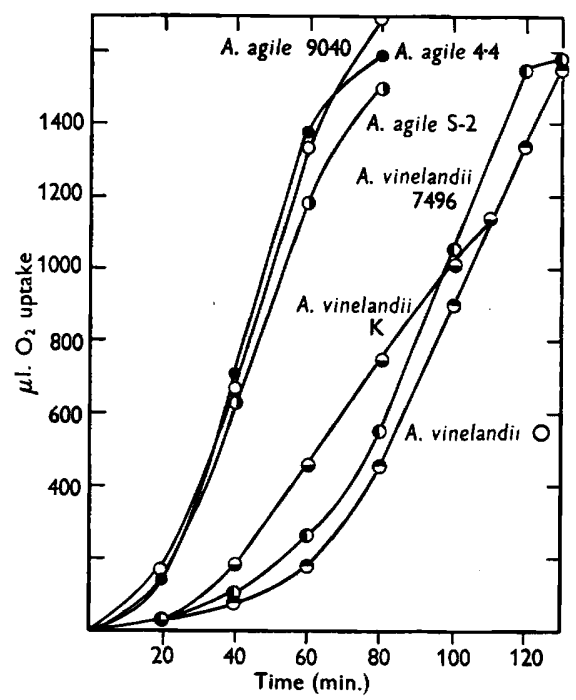

Fig. 3. Respiratory activity of sucrose-grown cells of Azotobacter vinelandii $\mathrm{O}$, K, and 7496 and Azotobacter agile 9040, 4.4, and S-2 on sodium succinate. 
not so clear-cut differences were obtained with $\alpha$-ketoglutarate and malate; with the strains we have used, however, succinate certainly would be the substrate of choice for screening.

The results with citrate call for special mention, particularly, since observations made in this laboratory with citrate first suggested this study. Extended experiments with the 14 strains, however, did not lend support to our original view that it might be used as a differentiating substrate. While these experiments were in progress, we learned through private communication with Dr N. Levy of Imperial Chemical Industries Ltd. that an important factor determining whether citrate (and probably other TCA intermediates) is utilized by Azotobacter spp., and probably other species, is the ratio of citrate: $\mathrm{Mg}^{++}$. Dr Levy kindly furnished us with a summary of his results* prior to their publication so that we were able to test the influence of this factor on 12 of the 14 strains. Three distinct responses, which were independent of the type of organism, were observed when the ratio citrate: $\mathrm{Mg}^{++}$was varied: $(a)$ one strain $(A$. vinelandii $\mathbf{O})$ adapted to citrate independently of the citrate: $\mathbf{M g}^{++}$ ratio; $(b)$ three strains ( $A$. vinelandii $7492,7496, \mathrm{~K}-\mathrm{S} 4$ ) did not adapt during these experiments (210 min.) even with the lowest citrate: $\mathrm{Mg}^{++}$ratio; $(c)$ the remaining strains did or did not adapt, depending on the citrate: $\mathrm{Mg}^{++}$ratio (see Tables 2 and 3 ).

Because a lowering of the citrate: $\mathrm{Mg}^{++}$ratio permitted citrate oxidation by 10 of the 14 strains, it was reasoned that an inhibitory factor in previous experiments had been the chelation of ions such as $\mathrm{Mg}^{++}$and $\mathrm{Ca}^{++}$by an excess citrate, rendering these unavailable for TCA cycle oxidations. Harris (1954) suggested the same type of inhibition of citrate oxidation by Azotobacter chroococcum; since calcium is required by the organism for maximum respira-

* We thank Dr Levy and his associates not only for supplying us with this information in time for testing on the collection we used but also for the courtesy of allowing us to quote from a letter:

'For A. vinelandii (Rothamsted strain 5921) response to citrate is governed by (i) citrate: magnesium ratio in the medium and (ii) concentration of $\mathrm{Mg}^{++}$and $\mathrm{Ca}^{++}$in the cells, in close conformity with a membrane equilibrium model for $\mathrm{Mg}(\mathrm{Ca})$ transfer, based on the $1: 1$ citrate: kation complex and citric acid dissociation. In growth experiments using 1 per cent mannitol medium with 5-40 p.p.m. Mg and c. 1 p.p.m. soluble $\mathrm{Ca}$, citrate stimulates fixation when the citrate: $\mathrm{Mg}$ ratio is not much above 1 , inhibits completely above 5 and extends the lag (with ultimate stimulation) at intermediate ratios. Raising soluble Ca to 10 p.p.m. roughly doubles these thresholds, i.e. in given cases adequate Ca will convert inhibition to normal or stimulated growth. For a range of organic anions (tartrate, malate, citrate, acetyl acetonate, E.D.T.A.) inhibitory power rises with the stability constant of the $1: 1$ complex.

Oxidation of citrate by resting cells can also be varied from complete to slight according to (i) and (ii) above. The oxygen-uptake curves for acetate, malate, succinate, and citrate under equivalent conditions show "lags" rising in that order from zero to $4-5 \mathrm{hr}$. This "lag" could be explained, not by enzyme adaptation or anion permeability change, but by initial rapid membrane equilibrium (extraction or other immobilization of $\mathrm{Mg}^{++}$and $\mathrm{Ca}^{++}$) followed by re-mobilization and accelerating oxidation as the anion is consumed. Acetate has virtually no chelating power and is attacked without delay; citrate has the highest stability constant in this series and the longest "lags". It is thus possible to set up with a single strain parallels to the behaviour of the different groups you mention.'

Obviously, concentrations and/or ratios of $\mathrm{Mg}^{++}$and citrate other than those used by ourselves (Table 3) might lead to variations in the results, for example, the recalcitrant strains of $A$. vinelandii might be induced to use citrate. 
Table 3. Influence of citrate: $\mathrm{Mg}^{++}$ratio on respiratory activity of whole azotobacter cells

\begin{tabular}{|c|c|c|c|c|c|}
\hline Strain & $\begin{array}{l}\text { Citrate: } \mathrm{Mg}^{++} \\
\text {ratio }\end{array}$ & $\begin{array}{l}\text { Citrate } \\
(\mu \mathrm{mole})\end{array}$ & $\begin{array}{c}\mathrm{Mg}^{++} \\
(\mu \mathrm{mole})\end{array}$ & $\begin{array}{l}\text { Lag period } \\
\text { (min.) }\end{array}$ & $\begin{array}{c}Q_{\mathrm{O}_{2}}(\mathrm{~N}) \\
\left(\mu \mathrm{l} . \mathrm{O}_{2} / \mathrm{hr} \cdot / \mathrm{mg} \cdot \mathrm{N}\right)\end{array}$ \\
\hline \multicolumn{6}{|c|}{ Azotobacter vinelandii } \\
\hline $\mathbf{O}$ & $\begin{array}{r}20: 1 \\
10: 1 \\
5: 1 \\
2: 1 \\
1: 1 \\
5: 0\end{array}$ & $\begin{array}{r}40 \\
20 \\
10 \\
8 \\
6 \\
5\end{array}$ & $\begin{array}{l}2 \\
2 \\
2 \\
4 \\
6 \\
0\end{array}$ & $\begin{array}{l}10 \\
10 \\
10 \\
10 \\
10 \\
10\end{array}$ & $\begin{array}{l}\mathbf{5 0 0 0} \\
\mathbf{5 9 0 0} \\
\mathbf{4 5 0 0} \\
\mathbf{4 5 0 0} \\
\mathbf{3 8 0 0} \\
\mathbf{3 1 0 0}\end{array}$ \\
\hline $\mathbf{K}$ & $\begin{array}{r}20: 1 \\
2: 1 \\
1: 1 \\
1: 1 \\
1: 2 \\
1: 1\end{array}$ & $\begin{array}{r}40 \\
8 \\
10 \\
14 \\
10 \\
6\end{array}$ & $\begin{array}{r}2 \\
4 \\
10 \\
14 \\
20 \\
6\end{array}$ & $\begin{array}{c}180-210 \\
180-210 \\
160 \\
170 \\
170 \\
180-210\end{array}$ & $\begin{array}{c}{ }^{*} \\
- \\
3200 \\
865 \\
1800 \\
-\end{array}$ \\
\hline 3 & $\begin{array}{r}20: 1 \\
1: 1 \\
1: 1\end{array}$ & $\begin{array}{r}40 \\
10 \\
6\end{array}$ & $\begin{array}{r}2 \\
10 \\
6\end{array}$ & $\begin{array}{l}210 \\
210 \\
200\end{array}$ & $\overline{-}$ \\
\hline \multicolumn{6}{|c|}{ Azotobacter agile } \\
\hline 9040 & $\begin{array}{r}20: 1 \\
10: 1 \\
5: 1 \\
3: 1 \\
2: 1 \\
1: 1 \\
1: 1 \\
5: 0\end{array}$ & $\begin{array}{r}40 \\
20 \\
10 \\
60 \\
8 \\
6 \\
40 \\
5\end{array}$ & $\begin{array}{r}2 \\
2 \\
2 \\
20 \\
4 \\
6 \\
40 \\
0\end{array}$ & $\begin{array}{c}180-210 \\
180-210 \\
180-210 \\
180-210 \\
150 \\
150 \\
180-210 \\
180-210\end{array}$ & $\begin{array}{l}- \\
- \\
- \\
1800 \\
2000 \\
- \\
-\end{array}$ \\
\hline $4 \cdot 4$ & $\begin{array}{r}20: 1 \\
1: 1 \\
1: 1\end{array}$ & $\begin{array}{l}40 \\
10 \\
18\end{array}$ & $\begin{array}{r}2 \\
10 \\
18\end{array}$ & $\begin{array}{c}180-210 \\
150 \\
170\end{array}$ & $\begin{array}{l}- \\
3400 \\
3800\end{array}$ \\
\hline 7494 & $\begin{array}{r}20: 1 \\
1: 1\end{array}$ & $\begin{array}{l}40 \\
10\end{array}$ & $\begin{array}{r}2 \\
10\end{array}$ & $\begin{array}{l}210 \\
160\end{array}$ & $\overline{2800}$ \\
\hline S-1 & $\begin{array}{r}20: 1 \\
1: 1 \\
1: 1\end{array}$ & $\begin{array}{r}40 \\
10 \\
6\end{array}$ & $\begin{array}{r}2 \\
10 \\
6\end{array}$ & $\begin{array}{l}210 \\
210 \\
190\end{array}$ & $\frac{-}{2180}$ \\
\hline S-2 & $\begin{array}{r}20: 1 \\
1: 1 \\
1: 1\end{array}$ & $\begin{array}{r}40 \\
10 \\
6\end{array}$ & $\begin{array}{r}2 \\
10 \\
6\end{array}$ & $\begin{array}{l}210 \\
160 \\
200\end{array}$ & $\begin{array}{r}\overline{850} \\
1100\end{array}$ \\
\hline S-3 & $\begin{array}{r}20: 1 \\
1: 1\end{array}$ & $\begin{array}{r}40 \\
6\end{array}$ & $\begin{array}{l}2 \\
6\end{array}$ & $\begin{array}{l}210 \\
200\end{array}$ & $\overline{2550}$ \\
\hline
\end{tabular}

tory activity, the lowering of the rate of oxygen uptake may arise from the formation of 'insoluble calcium citrate salts'. If a magnesium (calcium) deficiency were a factor in the low rate of citrate oxidation, it was reasoned that the presence of excess citrate would lower respiratory rate on other substrates oxidized through the TCA cycle. This was substantiated in part by the addition of acetate to Warburg vessels containing cells that had been preincubated with $40 \mu$ mole of citrate and $2 \mu$ mole of $\mathrm{MgSO}_{4}$ for approximately $1 \mathrm{hr}$. (Table 4). 


\section{DISCUSSION}

Before summarizing conclusions to be drawn from this study, two side observations of the research should be mentioned:

(1) Adaptive patterns of the strains have been tested over a 2-year period and found to be constant. Even more important, freshly isolated strains of the agile group possessed the same adaptive patterns as did stock strains which had been kept on laboratory media for many years. These data suggest that the patterns found are stable and representative of the organism in nature and not a laboratory artefact.

Table 4. Influence of preincubation with citrate on the respiratory activity of azotobacter cells on acetate

\begin{tabular}{|c|c|c|}
\hline \multirow{4}{*}{ Strain } & \multicolumn{2}{|c|}{$Q_{\mathrm{O}_{2}}(\mathrm{~N})$ values on acetate } \\
\hline & $\begin{array}{l}\text { Preincubation } \\
\text { without }\end{array}$ & $\begin{array}{l}\text { Preincubation } \\
\text { with } 40 \mu \text { mole }\end{array}$ \\
\hline & citrate & citrate \\
\hline & \multicolumn{2}{|c|}{$\left(\mu \mathrm{l} . \mathrm{O}_{2} / \mathrm{hr} . / \mathrm{mg} . \mathbf{N}\right)$} \\
\hline \multicolumn{3}{|c|}{ Azotobacter agile } \\
\hline $4 \cdot 4$ & 18,900 & 7,400 \\
\hline S-1 & 12,400 & 5,400 \\
\hline S-2 & 17,600 & 11,700 \\
\hline 7494 & 11,200 & 6,900 \\
\hline \multicolumn{3}{|c|}{ Azotobacter vinelandii } \\
\hline $\mathbf{O}$ & 14,600 & 4,500 \\
\hline $\mathbf{K}$ & 16,500 & 5,800 \\
\hline 3 & 13,200 & 7,100 \\
\hline K-S4 & 16,500 & $4,4,00$ \\
\hline
\end{tabular}

(2) The difficulty of comparing lag times without rigid control of the age of the organisms under observation can be ascertained from the data of Williams $\&$ Wilson (1954), in which lag times for Azotobacter vinelandii $\mathrm{O}$ on succinate and $\alpha$-ketoglutarate were shown to vary widely with the age of the organisms from 6 to $60 \mathrm{hr}$. However, since the present study was in part to evolve a simple technique that would facilitate identification of a questionable strain of Azotobacter an age variation of 15-24 hr. was allowed in the experiments. Within this range only succinate emerged as a clear 'indicator' substrate: A. agile organisms $15-24 \mathrm{hr}$. old had a lag period of $30 \mathrm{~min}$. or less, whereas $A$. vinelandii strains $15-24 \mathrm{hr}$. old had lag periods of at least $50 \mathrm{~min}$. Also within this range, a trend of lag differences between species on oxidation of malate and $\alpha$-ketoglutarate was noted; but a few strains of one species have lag times overlapping those of strains of the other species when comparisons are made between organisms that may vary as much as the allowed $10 \mathrm{hr}$. in age.

Independent of the particular mechanism concerned with adaptation, be it physical or biological, certain major conclusions appear permissible from these studies. First, ability to adapt to succinate and to a lesser extent to malate and $\alpha$-ketoglutarate might be useful criteria for differentiating between 
members of these two groups of Azotobacter spp. Secondly, the observations encourage the belief that similar and additional studies of this type (e.g. examination of cell-free extracts for characteristics, including concentration of specific enzymes) might be a powerful tool for more precise definition of an organism's physiology. Such definition should be particularly useful in classification of doubtful cases found in taxonomic studies of this and other micro-organisms. Whether the observed differences are sufficient for division into species in the present example is not a decision for the physiologist but for the expert in taxonomy. The physiologist can only ask that, if his field is to be used in making such decisions, recognition be taken of the advances in this area. Thus more modern methods will be increasingly utilized, methods that he believes might be more powerful and selective than those at present represented in Bergey's Manual of Determinative Bacteriology and other taxonomic manuals.

\section{REFERENCES}

Green, M. \& Wilson, P. W. (1953). The utilization of nitrate nitrogen by the azotobacter. J. gen. Microbiol. 9, 89.

Harris, J. O. (1954). A study of adaptation in Azotobacter. Proc. Soil Sci. Soc. Amer. 18, 154.

Horner, C. K. \& Allison, F. E. (1943). Utilization of fixed nitrogen by Azotobacter and the influence of nitrogen fixation. J. Bact. 47, 1.

Jensen, H. L. (1954). The Azotobacteriaceae. Bact. Rev. 18, 195.

Nelson, J. L., Kurtz, L. T. \& Bray, R. H. (1954). Rapid determination of nitrates and nitrites. Anal. Chem. 26, 1081.

Repaske, R. \& Wilson, P. W. (1953). Oxidation of intermediates of the tricarboxylic acid cycle by extracts of Azotobacter agile. Proc. nat. Acad. Sci., Wash. 39, 225.

Williams, A. M. \& Wilson, P. W. (1954). Adaptation of Azotobacter cells to tricarboxylic acid substrates. J. Bact. 67, 353.

Wilson, P. W. \& Knight, S. G. (1952). Experiments in Bacterial Physiology. Minneapolis, Minn.: Burgess Publishing Co.

(Received 8 November 1954) 